\title{
Fertility restoration of racing mare with persistent corpus luteum
}

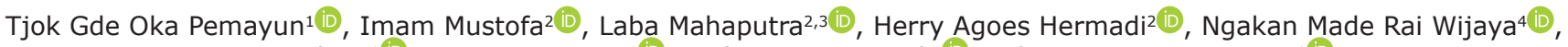
Sri Mulyati²(i), Suzanita Utama²(iD, Tjuk Imam Restiadi²(i) and Rimayanti Rimayanti²

1. Laboratory of Veterinary Reproduction, Faculty of Veterinary Medicine, Udayana University, JI. PB Sudirman, Denpasar, Bali 80233 Indonesia; 2. Division of Veterinary Reproduction, Faculty of Veterinary Medicine, Universitas Airlangga, Kampus C Mulyorejo, Surabaya 60115, Indonesia; 3. Head Section of Health and Husbandry of the Indonesian Equestrian Association, East Java Region, Kampus C Mulyorejo, Surabaya 60115, Indonesia; 4. Division of Basic Veterinary

Medicine, Faculty of Veterinary Medicine, Universitas Airlangga, Kampus C Mulyorejo, Surabaya 60115, Indonesia. Corresponding author: Imam Mustofa, e-mail: imam.mustofa@fkh.unair.ac.id

Co-authors: TGOP: oka_pemayun@unud.ac.id, LM: n.k.I.mahaputra@gmail.com, HAH: herry-a-h@fkh.unair.ac.id, NMRW: n.m.r.wijaya@gmail.com, SM: srimulyati_s3unair@yahoo.co.id, SU: suzanitautama@hotmail.com, TIR: tjukir@yahoo.com, RR: rimayanti@fkh.unair.ac.id

Received: 05-05-2021, Accepted: 02-08-2021, Published online: 08-09-2021

doi: www.doi.org/10.14202/vetworld.2021.2356-2361 How to cite this article: Pemayun TGO, Mustofa I, Mahaputra L, Hermadi HA, Wijaya NMR, Mulyati S, Utama S, Restiadi TI, Rimayanti R (2021) Fertility restoration of racing mare with persistent corpus luteum, Veterinary World, 14(9): 2356-2361.

\begin{abstract}
Background and Aim: Persistent corpus luteum (PCL) causes anestrus in mares. This study aimed to determine the effect of intrauterine prostaglandin F2 $\alpha(\mathrm{PGF} 2 \alpha)$ treatment on PCL of racing mares to restore fertility.

Materials and Methods: Twelve racing mares suspected with PCL were diagnosed using transrectal palpation and confirmed by serum progesterone (P4) concentration measurement. PGF2 $\alpha$ was infused intrauterine, followed by serum collection at 24, 48, and $72 \mathrm{~h}$ after. Estrous symptoms were monitored, and mating was conducted on day 3 of estrus with an earlier injection of $8.4 \mu \mathrm{g}$ gonadotropin-releasing hormone twice a day. Transrectal palpation was performed on days 21-30 to observe the corpus luteum. Pregnancy diagnosis was performed rectally on 40-45 days post-mating and confirmed using Doppler ultrasound scanning.

Results: Eleven of the 12 mares had PCL. There was a dramatic reduction in the P4 concentration following PGF $2 \alpha$ treatment of mares with PCL. All mares exhibited estrus $2.6 \pm 0.55$ days post-treatment with a P4 concentration of $0.12 \pm 0.12 \mathrm{ng} /$ $\mathrm{mL}$. Rectal palpation and P4 concentration on 21-30 days after estrous onset showed that all mares were ovulating. The evaluation of $\mathrm{P} 4$ concentration on days 40-45 post-mating showed that all mares were still in the luteal phase. However, the pregnancy rate was only $54.5 \%$ based on rectal palpation and Doppler ultrasound scanning.
\end{abstract}

Conclusion: Treatment of PCL in racing mares with an intrauterine infusion of PGF2 $\alpha$ restored the estrous cycle and induced ovulation and pregnancy.

Keywords: estrus, fertility, good health and well-being, ovulation, progesterone, racing mare.

\section{Introduction}

Horses are seasonally polyestrous, and the fertility traits of mares are affected by environmental factors [1]. The estrous cycle of mares differs between 18 and 22 days, with an average of 21 days [2]. The corpus luteum (CL) is relapsed by prostaglandin F2 $\alpha$ (PGF2 $\alpha$ ) secreted by endometrial around days 13-16 post-estrus in non-pregnant mares. The mares in good health and well-being are expected to reach a reproductive efficiency of one foal per year if there is no postpartum pathological problem. However, much happens during postpartum anestrus and anestrus in mares caused by persistent CL (PCL) [3]. This is because of the extended lifespan of unovulated follicles caused by the absence of the luteinizing hormone

Copyright: Pemayun, et al. Open Access. This article is distributed under the terms of the Creative Commons Attribution 4.0 International License (http://creativecommons.org/licenses/ by/4.0/), which permits unrestricted use, distribution, and reproduction in any medium, provided you give appropriate credit to the original author(s) and the source, provide a link to the Creative Commons license, and indicate if changes were made. The Creative Commons Public Domain Dedication waiver (http:// creativecommons.org/publicdomain/zero/1.0/) applies to the data made available in this article, unless otherwise stated. surge. Therefore, cumulus cells are directly converted to lutein cells, and they produce progesterone (P4) without ovulation [4]. Delayed ovulation results in immature CL, which in turn results in early embryonic death, and disturbance of the endometrium that diminishes or fails to release PGF2 $\alpha$. Hence PCL can be treated by the administration of PGF2 $\alpha$ [5].

To induce luteolysis, a single dose of PGF2 $\alpha$ intramuscular treatment is routinely used permitting a subsequent return to the estrus of mares [6]. However, by intramuscular administration, the migration of PGF $2 \alpha$ from the injection site to the ovaries of a mare is through the whole body (systemically) [7], which requires a high dose. There has not been reported use of intrauterine PGF $2 \alpha$ for estrus induction to restore fertility in racing mares with PCL.

Therefore, this study aimed to determine the effect of intrauterine PGF2 $\alpha$ treatment in racing mares with PCL to restore fertility.

\section{Materials and Methods}

\section{Ethical approval}

The experimental procedure was approved by No. 266/HRECC.FODM/VI/2019, by the Animal 
Care and Use Committee, Universitas Airlangga, Surabaya, Indonesia.

\section{Study period and location}

This study was conducted from July to November 2020 at Trawas stable, Mojokerto, and Kenjeran stable, Surabaya, East Java. Trawas stable is located at latitude S $7^{\circ} 39^{\prime} 59.3568^{\prime \prime}$, longitude E $112^{\circ} 35^{\prime}$ 15.8316", and altitude +837 meters above sea level (ASL). The climate of Trawas is wet tropical with significant rainfall most months and a short dry season. The relative humidity is $63.91-90.15 \%$, and temperature is $\pm 20.6^{\circ} \mathrm{C}$, yearly rainfall is about $\pm 3089 \mathrm{~mm}$, and \pm 210 rainy days per year. Kenjeran Stables is located at latitude S $7^{\circ} 14^{\prime} 57.01$ ', longitude E $112^{\circ} 45^{\prime} 2.99$ ", and altitude one meter ASL. Surabaya is a dry tropical climate with humidity $68 \%-84 \%$, average temperature $\pm 28^{\circ} \mathrm{C}$, and yearly rainfall is about $\pm 848 \mathrm{~mm}$, and \pm 174 rainy days per year. Meanwhile, serum progesterone measurement was conducted at Sub Laboratory of Endocrinology, Laboratory of Veterinary Obstetrics, Division of Veterinary Reproduction, Faculty of Veterinary Medicine, Universitas Airlangga.

\section{Animals}

Twelve mares (after 2-5 years as racing horses) were used for this study. The mares were bred in Trawas stable, Mojokerto and Kenjeran Stables, Surabaya, East Java, Indonesia. These mares were the patients of the Health and Husbandry Section of Horse Race Club, East Java Region.

\section{PCL diagnosis}

The mares were diagnosed with PCL based on behavioral observation and history of non-cycling and non-return to estrus 2-4 months post-mating. The rectal palpation was performed for the presence of CL and confirmed by the measurement of serum $\mathrm{P} 4$ concentration before treatment [8].

Serum collection and P4 concentration measurement Mares' blood samples $(5 \mathrm{~mL})$ were obtained from the jugular vein before treatment, at 24, 48, and $72 \mathrm{~h}$ post-treatment; $21-30$ days post-estrus; and 40-45 days post-mating. P4 was measured using an enzyme-linked immunosorbent assay (ELISA Kit, GBC, Taiwan).

\section{Treatment, estrus detection, mating, and pregnancy diagnosis}

The PCL mares were treated using 5 mg PGF $2 \alpha$ (Lutalyse, Upjohn) dissolved in $3 \mathrm{~mL}$ aqua dest and then infused into the uterine lumen using a $24 \mathrm{G}$ Foley catheter. Estrus detection was based on visual observation and intravaginal examination. The mare in standing heat exhibited vulvar winking followed by urination, a clinical manifestation which was absent in other mammals. The intravaginal examination was performed using a vaginoscopy (Polansky, MediTools Pty Ltd, Australia) two days after treatment to detect cervical dilation and the presence of cervical discharge. The mare did not exhibit cervical dilatation nor cervical discharge on day 2 ; estrus detection was repeated on day 3 . The estrous mares were confirmed the day after with a teaser stallion $[9,10]$.

Natural mating was conducted on day 3 of standing heat by previously providing an intramuscular injection of $8.4 \mu \mathrm{g}$ synthetic gonadotropin-releasing hormone $(\mathrm{GnRH})$ (Buserelin acetate, Concepts, AgroVet market, Peru) twice a day. Transrectal palpation was conducted on days 21-30 after mating to palpate the presence of the CL on the ovaries and to determine the position of CL in the left or right ovary. Pregnancy diagnosis through transrectal palpation was conducted on 40-45 days post-mating and confirmed using a Doppler ultrasound [9,11] BT-200 scanner (Bistos, South Korea).

\section{Statistical analysis}

Statistical analyses were conducted at a 95\% significance level using Statistical Package for the Social Sciences version 23.0 (IBM Corp., Armonk, NY, USA). Data of progesterone concentrations on days $0,4,48$, and 72 were studied using a general linear model repeated measures [12]. Meanwhile, analysis of data frequency of estrus and pregnancy of mare were studied using Chi-square test [13].

\section{Results}

Transrectal palpation diagnosis of PCL suspected mares based on clinical manifestations showed that all mares had CL in their ovaries. Furthermore, examination showed that $91.7 \%(11 / 12)$ of the mares were PCL positive with a range of serum $\mathrm{P} 4$ concentrations of $2.6-9.5 \mathrm{ng} / \mathrm{mL}$ (average $5.03 \pm 2.68 \mathrm{ng} / \mathrm{mL}$ ) on day 0 (before treatment). Meanwhile, 8.3\% (1/12) was negative for PCL with a P4 concentration of $0.5 \mathrm{ng} / \mathrm{mL}$.

A quarter decrease in serum P4 concentration was noticed from pre-treatment to $24 \mathrm{~h}$ post-treatment $(\mathrm{p}<0.01), 1 / 8$ reduction from pre-treatment to $48 \mathrm{~h}$ post-treatment $(\mathrm{p}<0.01)$, and a reduction by half from 24 to $48 \mathrm{~h}$ post-treatment $(\mathrm{p}<0.05)$. Meanwhile, there was no significant $(>0.05)$ decrease in serum $\mathrm{P} 4$ concentration 48-72 h after PGF2 $\alpha$ treatment (Table-1).

All PCL diagnosed mares exhibited estrous signs after PGF $2 \alpha$ treatment with serum P4 concentrations $<0.2 \mathrm{ng} / \mathrm{mL}$. The estrous rate was $36.4 \%(4 / 11)$ at $48 \mathrm{~h}$ and $63.6 \%(7 / 11)$ at $72 \mathrm{~h}$ after PGF2 $\alpha$ treatment, with $2.6 \pm 0.5$ days average (Table-2). All mares were ovulating based on the finding of CL in their ovaries in the transrectal examination on 21-30 days after estrous onset, P4 concentration was higher than $1 \mathrm{ng} / \mathrm{mL}$. Those CLs' distribution was $72.7 \%(8 / 11)$ in the right ovary and $27.3 \%(3 / 11)$ in the left ovary. The average $\mathrm{P} 4$ concentrations of mares on 40-45 days post-mating were $2.80 \pm 0.59 \mathrm{ng} / \mathrm{mL}$ in the range of $1.9-3.6 \mathrm{ng} / \mathrm{mL}$. The P4 concentration of mares based on the position of CL was $2.82 \pm 0.65 \mathrm{ng} / \mathrm{mL}$ in the right ovary and $2.7 \mathrm{ng} / \mathrm{mL}$ in the left (Table-3). The pregnancy rate was $54.5 \%(6 / 11)$, given at the right uterine horn was $45.5 \%(5 / 11)$, and at the left uterine horn was $9 \%$ 
Table-1: Serum P4 concentrations $(\mathrm{ng} / \mathrm{mL})$ before and after PGF2a treatments.

\begin{tabular}{lcccc}
\hline Parameter & Before & \multicolumn{3}{c}{ Hours after PGF2a treatment } \\
\cline { 3 - 5 } & (Day 0) & $\mathbf{2 4}$ & $\mathbf{4 8}$ & $\mathbf{7 2}$ \\
\hline Average & $5.03 \pm 2.68^{\mathrm{a}}$ & $1.33 \pm 1.01^{\mathrm{b}}$ & $0.61 \pm 0.65^{\mathrm{c}}$ & $0.13 \pm 0.11^{\mathrm{c}}$ \\
Range & $2.6-9.5$ & $0.1-2.7$ & $0.00-1.7$ & $0.00-0.4$ \\
Decreased concentration (\%) & - & 73.56 & 87.87 & 97.42 \\
\hline
\end{tabular}

Different superscripts in the same row were significantly different $(p<0.05)$ in general linear model repeated measure test. PGF2 $a=$ Prostaglandin F2a

Table-2: Estrous responses and P4 concentration at estrus after PGF2a treatment.

\begin{tabular}{lccc}
\hline \multirow{2}{*}{ Parameter } & \multicolumn{3}{c}{ Hours after PGF2a treatment } \\
\cline { 2 - 4 } & $\mathbf{2 4}$ & $\mathbf{4 8}$ & $\mathbf{7 2}$ \\
\hline Estrous mares & 0 & $36.4 \%(4 / 11)^{\mathrm{b}}$ & $63.6 \%(7 / 11)^{\mathrm{a}}$ \\
P4 & - & $0.075 \pm 0.096$ & $0.16 \pm 0.14$ \\
concentration at & & & \\
estrus $(\mathrm{ng} / \mathrm{mL})$ & & & \\
\hline
\end{tabular}

Different superscripts in the same row were significantly different $(p<0.05)$ in the Chi-square test. PGF2 $a=$ Prostaglandin F2a

Table-3: The fertility of mares after PGF2a treatment.

\begin{tabular}{lccc}
\hline Parameter & \multicolumn{2}{c}{ Position } & Total \\
\cline { 2 - 3 } & $\begin{array}{c}\text { Right ovaries/ Left ovaries/ } \\
\text { horns }\end{array}$ & \\
\hline $\begin{array}{l}\text { Developing } \\
\text { CL }(\%)\end{array}$ & $72.7 \%(8 / 11)^{\mathrm{a}}$ & $27.3 \%(3 / 11)^{\mathrm{b}}$ & $\begin{array}{c}100 \% \\
(11 / 11)\end{array}$ \\
$\begin{array}{l}\text { P4 averages } \\
(\mathrm{ng} / \mathrm{mL})\end{array}$ & $2.82 \pm 0.65$ & 2.7 & $2.80 \pm 0.59$ \\
$\begin{array}{l}\text { Pregnancy } \\
\text { rate }\end{array}$ & $45.5 \%(5 / 11)^{\mathrm{a}}$ & $9.0 \%(1 / 11)^{\mathrm{b}}$ & $54.5 \%$ \\
\hline
\end{tabular}

Different superscripts in the same row were significantly different $(p<0.05)$ in the Chi-square test. PGF2 $a=$ Prostaglandin F2a

(1/11). Doppler ultrasound scanning showed two digital wave groups: $59-73$ beats per minute (bpm) and $181-210 \mathrm{bpm}$.

\section{Discussion}

The CL is a pivotal structure for controlling the estrous cycle and maintaining pregnancy [14]. The $\mathrm{CL}$ is formed after ovulation and usually works for 14-15 days in non-pregnant mares. It is then regressed because of the prostaglandin release from the endometrium. A sudden and complete reduction in $\mathrm{P} 4$ concentrations in cycling mare due to luteolysis began on day 13 , whereas in the PCL mares, the P4 concentrations slowly declined after day 12 and not fully decreased to the basal concentrations [5]. The corpora lutea that failed to regress at the normal time were considered pathologically persistent CL. The CL persisted for 2-3 months, and the mare did not show estrous behavior [7]. Of the 12 mares diagnosed with PCL, one was not in the PCL category because of a P4 concentration of $0.5 \mathrm{ng} / \mathrm{mL}$ (day 0 ).

Meanwhile, the other 11 mares were confirmed to have PCL with a range of serum P4, concentrations of 2.6-9.5 ng/mL (Table-1). PCL diagnosis was conducted using behavioral observations, ovarian transrectal palpation, and measurement of $\mathrm{P} 4$ concentrations [8]. Mares with PCL have a good tone of the cervix and uterus on transrectal palpation [15], and P4 concentrations of $>1.0 \mathrm{ng} / \mathrm{mL}$, indicating luteal activity [16].

\section{P4 concentrations before and after PGF2 $\alpha$ treatment}

PGF $2 \alpha$ is widely used in practice to control heat cycles in the mare. PGF2 $\alpha$, available as natural or synthetic, has a unique function of destroying the CL [5]. Sudden decreases of P4 concentration follow the regression of CL. The P4 basal concentration causes the loss of negative feedback to the hypothalamus, the release of GnRH followed by the release of follicle-stimulating hormone (FSH) from the anterior pituitary. The FSH induces follicle development, but when the estrogen derived from the follicles is quantitatively enough in the bloodstream, clinical symptoms of estrus are shown [2].

Hormone concentrations are highly vital to the reproductive efficiency of mares [17]. Here, serum P4 concentrations were reduced from day 0 to 24 and $48 \mathrm{~h}$ following PGF2 $\alpha$ treatment and stabilized in 48-72 h. The reduction in the $\mathrm{P} 4$ percentage was getting more significant daily (Table-1). The average $\mathrm{P} 4$ concentration on day 0 was $5.03 \pm 2.68 \mathrm{ng} / \mathrm{mL}$, which means that the mares were positive for PCL. Previously, a report showed that at the beginning of luteolysis, the P4 concentration in PCLs was $5.0 \pm 0.5 \mathrm{ng} / \mathrm{mL}$ [4].

In this study, the mare's PCL treatment was performed using intrauterine infusion of PGF2 $\alpha$. The PGF $2 \alpha$ travels to the ovary and CL as the target. The luteal cell membranes are highly efficient in capturing the PGF $2 \alpha$ molecules [5]. Luteolysis caused the loss of lutein cells steroidogenic capacity by apoptotic or non-apoptotic mechanisms due to disintegration of the CL [2]; thereby P4 concentration reduced fast and was subsequently followed by folliculogenesis and estrus [18].

\section{Estrous responses after PGF2 $\alpha$ treatment}

Mares with PCL possessed a defect in PGF $2 \alpha$ secretion [7]. Therefore, the administration of PGF2 $\alpha$ could be used to prompt luteolysis and allow a subsequent return to estrus [6]. Here, all mares showing estrous signs, including excitement, sweating, and mild colic symptoms following PGF $2 \alpha$ treatment, were confirmed by blood serum P4 concentrations of $<0.2 \mathrm{ng} / \mathrm{mL}$ (Table-2). Moreover, an earlier study [19] 
reported that following 20-35 min PGF2 $\alpha$ administration, the mares exhibited restless, sweating, spasm of pelvic muscle, and mild colic symptoms. The percentage of mares that showed estrous signs on day 2 was $36.36 \%(4 / 11)$, and those on day 3 were $63.63 \%(7 / 11)$, on an average of $2.6 \pm 0.5$ days post-PGF $2 \alpha$ treatment (Table-2). The onset of mare estrus after PGF2 $\alpha$ was 2.5 days [20], and ovulation occurred 8.4 days following PGF $2 \alpha$ treatment [6].

\section{Fertility of mares after PGF2 $\alpha$ treatment}

Indicator of mare fertility, among others, is the development of CL following estrus and ovulation. Once ovulation occurs, granulosa and theca cells undergo functional and structural changes; they form $\mathrm{CL}$ and produce $\mathrm{P} 4$ [21,22]. All of the mares with PCL treated with PGF2 $\alpha$ followed by buserelin (synthetic $\mathrm{GnRH}$ ) injection on day 2 of estrous signs in this study revealed ovulation, indicated by the finding of CL on transrectal palpation, and confirmed by $\mathrm{P} 4$ concentration (Table-3). Single injection of buserelin in delayed estrus of a mare effectively induces ovulation [10].

The distribution of CL formation was $72.7 \%$ $(8 / 11)$ in the right ovary and $27.3 \%(3 / 11)$ in the left ovary. This is because the mare's right ovary is more active than the left ovary. Follicle density, pre-antral follicles per ovarian fragment, and area of ovary structure (antral follicles and CL) of the right ovary of the mare were higher than that of the left ovary [23]. This result differed from the previous study [24], which reported that the relationship between follicle development and regressed CL was $8 \%$ ipsilateral, and $24 \%$ was contralateral [7]. These differences can be resulted from the small number of data in this study.

All mares treated in this study showed a $<0.5 \mathrm{ng} / \mathrm{mL} \mathrm{P} 4$ concentration during the estrus (Table-2) and $2.80 \pm 0.59 \mathrm{ng} / \mathrm{mL}$ with a range of 1.9$3.6 \mathrm{ng} / \mathrm{mL}$ on $40-45$ days post-mating (Table-3). The low concentration of $\mathrm{P} 4$ at estrus followed by a higher P4 concentration starting 4 days after the onset of estrus indicated ovulation followed by CL development [25]. The CL was detected rectally in the ovaries of mares on 21-30 days post-estrus.

Although all treated mares with PCL ovulated, unfortunately, the pregnancy rate was $54.5 \%(6 / 11)$ only. The pregnancy rate in this study was lower than those in Arabian mares (74\%) [9], although the breeding in this study was performed using natural mating. The sperm concentration, total number of sperm, and percentage of progressively motile sperm in the ejaculate were higher in natural mating than in artificial insemination [26]. A low-quality ovum obtained from the restoration of the ovarian function following PCL may cause the pregnancy failure. A study reported that $\mathrm{P} 4$ concentration at the beginning of luteolysis in mares with PCL was lower than those in cycling mares [4], resulting in embryos with a lower quality grade, smaller diameter, and earlier embryo stage compared to normal embryos [27].
Embryo development can be hampered following improper progestin supply when the embryo reaches the uterus [21]. Adequate P4 concentrations are vital mediators of the appropriate embryo-maternal environment during early pre-implantation embryo development $[28,29]$. The $45.45 \%$ of mares may fail to become pregnant in this study because of inadequate $\mathrm{P} 4$ concentration during post-mating. All those mares have a $\mathrm{P} 4$ concentration of $1.9-3.6 \mathrm{ng} / \mathrm{mL}$ on 40-45 days. The endogenous P4 concentrations of $>4.0 \mathrm{ng} / \mathrm{mL}$ are considered adequate to maintain pregnancy. Mares with P4 concentrations $<4.0 \mathrm{ng} / \mathrm{mL}$ were at risk of pregnancy loss [20]. The high P4 concentrations were vital for inhibiting myometrium contraction [30] because the connection between the trophoblast layer of the allantochorion and the endometrium's luminal epithelium was less stable before day 40 of pregnancy [31].

Here, mares' pregnancy diagnosis was performed by transrectal palpation and confirmed using Doppler ultrasound scanning. Transrectal palpation accurately determined 40-45 days of mare pregnancy, based on the finding of a round-shaped amnion sac $(6-10 \mathrm{~cm}$ in diameter) [32]. On Doppler ultrasound scanning, there were two groups of digital waves. The digital wave of 59-73 bpm was the uterine artery pulse and 181-210 bpm was the fetal heartbeat. The $1^{\text {st }}$ time fetal heartbeat could be monitored on day 24 of the pregnancy period [33] and can reach $>150 \mathrm{bpm}$ at the subsequent pregnancy periods [34]. Meanwhile, the lower digital wave was defined as a uterine artery pulse, slightly different between early and later pregnancy but not found in non-pregnant mares [35].

There are few pharmacological methods to improve the function of the CL to sustain the pregnancy of the mares [14]. The progestin injection [21] or human chorionic gonadotropin promised increased pregnancy rates and reduced pregnancy loss [15]. The demerits of this study are that it did not administer the addition of hormones to maintain the pregnancy. The injection of GnRH that was conducted before mating improved the ovulation rate. Its effects were only for a short time and theoretically would not improve CL function. Post-mating treatment to ensure P4 concentration adequacy in circulation should concern future PCL treatment of mares.

\section{Conclusion}

The intrauterine PGF $2 \alpha$ treatment on racing mares with PCL restored estrous cycle, ovulation, and pregnancy after mating. However, the pregnancy rate was low (54.5\%).

\section{Authors' Contributions}

TGOP, LM, and IM: Conception and design of the study. TGOP, LM, HAH, NMRW, and TIR: Acquisition of data. IM, SM, SU, and RR: Analysis and interpretation of data. TGOP, LM, and RR: Drafted the manuscript. IM, SU, and TIR: Critical 
review/revision. SU and SM: ELISA. All authors read and approved the final manuscript.

\section{Acknowledgments}

This research was supported by funding from the Laboratory of Veterinary Obstetrics, Universitas Airlangga, Indonesia (Grant number: 104/UN3.1.6/ LOG/2020). The authors are also grateful to the owners of the horses from the stables in Mojokerto and Kenjeran that were used in this study. The authors also thank the owner horse in Trawas Stables and Kenjeran Stables, East Java, Indonesia.

\section{Competing Interests}

The authors declare that they have no competing interests.

\section{Publisher's Note}

Veterinary World remains neutral with regard to jurisdictional claims in published institutional affiliation.

\section{References}

1. Çilek, S. (2008) Environmental factors affecting reproductive performance of mares. Indian J. Anim. Sci., 78(12): 1380-1383.

2. Satué, K. and Gardón, J.C. (2013) A review of the estrous cycle and the neuroendocrine mechanisms in the mare. $J$. Steroids Horm. Sci., 4(2): 115.

3. Santos, V.G., Bettencourt, E.M. and Ginther, O.J. (2015) Long-term characteristics of idiopathic persistent corpus luteum in the mare. Theriogenology, 84(2): 242-251.

4. Santos, V.G., Bettencourt, E.M. and Ginther, O.J. (2015) Hormonal, luteal, and follicular changes during initiation of persistent corpus luteum in mares. Theriogenology, 83(4): 757-765.

5. Ginther, O.J., Baldrighi, J.M., Siddiqui, M.A., Bashir, S.T. and Rakesh, H.B. (2016) Mechanism for greater frequency of contralateral than ipsilateral relationships between corpus luteum and ovulatory follicle for wave 3 in heifers. Theriogenology, 85(3): 361-367.

6. Burden, C.A., McCue, P.M. and Ferris, R.A. (2015) Effect of cloprostenol administration on interval to subsequent ovulation and anovulatory follicle formation in quarter horse mares. J. Equine Vet. Sci., 35(6): 531-535.

7. Ginther, O.J., Castro, T., Baldrighi, J.M., Wolf, C.A. and Santos, V.G. (2016) Defective secretion of prostaglandin F2 $\alpha$ during development of idiopathic persistent corpus luteum in mares. Domest. Anim. Endocrinol., 55(4): 60-65.

8. McCue, P.M. (2015) Chapter 161 Ovarian abnormalities. In: Sprayberry, K.A. and Robinson, N.E., editors. Robinson's Current Therapy in Equine Medicine. $7^{\text {th }}$ ed. WB Saunders, Philadelphia, PA. p676-679.

9. Çilek, S. (2009) The survey of reproductive success in Arabian horse breeding from 1976 to 2007 at Anadolu state farm in Turkey. J. Anim. Vet. Adv., 8(2): 389-396.

10. Miki, W., Oniyama, H., Takeda, N., Kimura, Y., Haneda, S., Matsui, M., Taya, K. and Nambo, Y. (2016) Effects of a single use of the GnRH analog buserelin on the induction of ovulation and endocrine profiles in heavy draft mares. $J$. Equine Sci., 27(4): 149-156.

11. da Silva, E.S.M., de Figueiredo Pantoja, J.C., Puoli, J.N.P. and Meira, C. (2015) Ultrasonography of the conceptus development from days 15 to 60 of pregnancy in non-cyclic recipient mares. Ciênc. Rural, 45(3): 512-518.

12. Singh, V., Rana, R.K. and Singhal, R. (2013) Analysis of repeated measurement data in the clinical trials. J. Ayurveda
Integr. Med., 4(2): 77-81.

13. Schober, P. and Thomas, R. (2019) Chi-square tests in medical research. Anesth. Analg., 129(5): 1193.

14. Sieme, H., Lüttgenau, J., Sielhorst, J., Martinsson, G., Bollwein, H., Thomas, S. and Burger, D. (2015) Improving the formation and function of the corpus luteum in the mare. Rev. Bras. Reprod. Anim., 39(1): 117-120.

15. Alonso, M.A., Silva, L.A., Affonso, F.J., Lemes, K.M., Celeghini, E., Lançoni, R., Carvalho, H.F. and de Arruda, R.P. (2019) Effect of hCG application at different moments of the estrous cycle on corpus luteum and uterine vascularization and serum progesterone concentration in mares. Anim. Reprod., 16(2): 317-327.

16. Panzani, D., Di Vita, M., Lainé, A.L., Guillaume, D., Rota, A., Tesi, M., Vannozzi, I. and Camillo, F. (2017) Corpus luteum vascularization and progesterone production in autumn and winter cycles of the mare: Relationship between ultrasonographic characteristics of corpora lutea and plasma progesterone concentration in the last cycles before anestrus. J. Equine Vet. Sci., 56(9): 35-39.

17. Vance, C.K., King, E.H., Bowers, S.D., Ryan, P.L., Walters, K. and Shappell, N.W. (2019) Reproductive performance of mares fed dietary zearalenone. Front. Vet. Sci., 6(11): 423.

18. Ginther2012, O.J. and Beg, M.A. (2012) Dynamics of circulating progesterone concentrations before and during luteolysis: A comparison between cattle and horses. Biol. Reprod., 86(6): 170.

19. Shrestha, H.K., Beg, M.A., Burnette, R.R. and Ginther, O.J. (2012) Plasma clearance and half-life of prostaglandin F2alpha: A comparison between mares and heifers. Biol. Reprod., 87(1): 18-16.

20. Satué, K. and Gardon, J.C. (2020) Physiological and clinical aspects of the endocrinology of the estrous cycle and pregnancy in mares. Open access peer-reviewed chapter In: Animal Reproduction in Veterinary Medicine. IntechOpen, London. p11.

21. Pinto C. (2020) Impact of the corpus luteum on survival of the developing embryo and early pregnancy in mares. Theriogenology, 150(7): 374-381.

22. Ginther, O.J., Baldrighi, J.M., Castro, T., Wolf, C.A. and Santos, V.G. (2016) Concentrations of progesterone, a metabolite of PGF2 $\alpha$, prolactin, and luteinizing hormone during development of idiopathic persistent corpus luteum in mares. Domest. Anim. Endocrinol., 55(4): 114-122.

23. Alves, K.A., Alves, B.G., Gastal, G.D., de Tarso, S.G., Gastal, M.O., Figueiredo, J.R., Gambarini, M.L. and Gastal, E.L. (2016) The mare model to study the effects of ovarian dynamics on preantral follicle features. PLoS One, 11(2): e0149693.

24. Ginther, O.J. (2019) Intraovarian spatial and vascular harmony between follicles and corpus luteum in monovulatory heifers, mares, and women. Theriogenology, 128(4): 31-39.

25. Cortés-Vidauri, Z., Aréchiga-Flores, C., RincónDelgado, M., Rochín-Berumen, F., López-Carlos, M. and Flores-Flores, G. (2018) Mare reproductive cycle: A review. Abanico Vet., 8(3): 14-41.

26. Kareskoski, M., Venhoranta, H., Virtala, A.M. and Katila, T. (2019) Analysis of factors affecting the pregnancy rate of mares after inseminations with cooled transported stallion semen. Theriogenology, 127(3): 7-14.

27. Aurich, C. and Budik, S. (2015) Early pregnancy in the horse revisited does exception prove the rule? J. Anim. Sci. Biotechnol., 6(1): 50.

28. Leisinger, C.A., Klein, C., Markle, M.L., Premanandan, C., Sones, J.L., Pinto, C. and Paccamonti, D.L. (2019) Altered gene expression in embryos and endometrium collected on day 8 of induced a luteal cycles in mares. Theriogenology, 128(4): 81-90.

29. Klein C. (2015) Pregnancy recognition and implantation of the conceptus in the mare. Adv. Anat. Embryol. Cell Biol., 216(3): 165-188

30. Yin, Z., Li, Y., He, W., Li, D., Li, H., Yang, Y., Shen, B., 
Wang, X., Cao, Y. and Khalil, R.A. (2017) Progesterone inhibits contraction and increases TREK-1 potassium channel expression in late pregnant rat uterus. Oncotarget, 9(1): 651-661.

31. Leisinger, C.A., Medina, V., Markle, M.L., Paccamonti, D.L. and Pinto, C. (2018) Morphological evaluation of day 8 embryos developed during induced a luteal cycles in the mare. Theriogenology, 105(1): 178-183.

32. Mustofa, I., Utama, S., Restiadi, T.I., Mulyati, S. and Lestrari, T.D. (2019) Animal Obstetrics. Airlangga University Press, Surabaya. p1-3, 32-33.

33. Paolucci, M., Palombi, C., Sylla, L., Stradaioli, G. and Monaci, M. (2012) Ultrasonographic features of the mule embryo, fetus and fetal-placental unit. Theriogenology, 77(2): 240-252.

34. Murase, H., Endo, Y., Tsuchiya, T., Kotoyori, Y., Shikichi, M., Ito, K., Sato, F. and Nambo, Y. (2014) Ultrasonographic evaluation of equine fetal growth throughout gestation in normal mares using a convex transducer. J. Vet. Med. Sci., 76(7): 947-953.

35. Klewitz, J., Struebing, C., Rohn, K., Goergens, A., Martinsson, G., Orgies, F., Probst, J., Hollinshead, F., Bollwein, H. and Sieme, H. (2015) Effects of age, parity, and pregnancy abnormalities on foal birth weight and uterine blood flow in the mare. Theriogenology, 83(4): 721-729.

$* * * * * * * *$ 